\title{
Immune Enhancement of Hericium erinaceum Mycelium Cultured in Submerged Medium Supplemented with Ginseng Extract
}

\author{
Hoon Kim, Kyung-Soo Ra*, Jong-Hyun Hwang ${ }^{* *}$ and ${ }^{\dagger}$ Kwang-Won $\mathrm{Yu}^{* *}$ \\ $R \& D$ Center, CosisBio Corporation Limited, Chungbuk 365-863, Korea \\ *Division of Food Beverage and Culinary Arts, Daegu Technical University, Daegu 704-721, Korea \\ ${ }^{* *}$ Dept. of Food and Nutrition, Korea National University of Transportation, Chungbuk 368-701, Korea
수삼 추출물 첨가 액체배지에서 배양된 노루궁뎅이버섯 균사체의 면역활성 증진
김훈 · 나경수" · 황종현"* · 유광원"
(주)코시스바이오 기업부설연구소, "대구공업대학교 호텔외식조리계열, "한국교통대학교 식품영양학과 \\ 국문요약
}

\begin{abstract}
본 연구는 mushroom complete medium(MCM) 액체배지에 수삼 추출물 $\left(\mathrm{GE}, 65^{\circ} \mathrm{Bx}\right)$ 을 첨가하여 면역활성이 증진된 노루궁뎅이버섯(Hericium erinaceum) 균사체를 배양하고, 균사체로부터 활성다당성분을 분획하고자 하였다. $\mathrm{MCM}$ 에 대하여 $\mathrm{GE}$ 를 5,10 과 $15 \%(\mathrm{v} / \mathrm{v})$ 첨가한 액체배지에서 균사체를 배양하고, 각각의 조다당획분(HE-GE-5-CP, HE-GE-10-CP 와 HE-GE-15-CP)으로 분획하여 면역활성을 측정한 결과, HE-GE-10-CP는 HE-GE-5-CP와 HE-GE-15-CP보다 높은 활 성을 나타내었으며, $\mathrm{GE}$ 를 첨가하지 않은 $\mathrm{MCM}$ 에서 배양된 균사체 조다당획분(HE-CP)보다 유의적으로 증진된 면역활 성을 나타내었다. 또한, HE-GE-10-CP의 DEAE-Sepharose CL-6B 분획물 중 가장 높은 활성을 나타낸 HE-GE-10-CP-II획 분은 대조군인 $\mathrm{HE}-\mathrm{CP}$ 의 어떠한 획분보다도 유의적으로 높은 면역활성과 암 전이 억제활성을 나타내었다. 한편, 활성 획분인 HE-GE-10-CP-II는 arabinose, rhamnose, galactose, glucose와 uronic acid(molar ratio; 0.34:0.26:0.99:1.00:0.39)로 구성되어 있으나, 대조군인 HE-CP의 동일용매 용출획분으로서 HE-GE-10-CP-II보다는 활성이 낮은 HE-CP-II는 fucose, mannose, galactose와 glucose(molar ratio; 0.32:0.55:1.00:0.96)를 함유하여 다른 구성당 분포를 나타내었다. 따라 서 노루궁뎅이버섯 균사체 액체배양에서 수삼 추출물 첨가는 균사체의 구성당 변화를 통한 면역활성 증진에 관여하 는 것으로 사료되어 기능성 소재 개발에 유용할 것으로 사료된다.
\end{abstract}

Key words: Hericium erinaceum, ginseng extract, submerged culture, immunomodulating activity, polysaccharide

\section{INTRODUCTION}

Much interest has been generated for biotechnological methods in the production of polysaccharides that can be applied within the food, pharmaceutical, cosmetic, and other industries. The majority of polysaccharides with various physiological activities are frequently derived from fungi, especially mushrooms ( $\mathrm{Yu}$ et al. 2005; Yoon et al. 2008). Some of these polysaccharides, such as Lentinan from Lentinus edodes fruit bodies, Schizophyllan from Schizophyllum commune culture filtrates, Grifolan from Grifola frondosa, and polysaccharide-K (PSK) from Coriolus versicolor culture mycelia, are now used in clinics (Fisher \& Yang 2002; Isoda et al. 2009). Moreover, polysaccharides from mushrooms enhance and stimulate the immune system of humans and mice, and are thus called biological response modifiers (BRMs) (Yoon et al. 2008; Deng et al. 2009).

Hericium erinaceum (bearded tooth mushroom) is a traditional edible mushroom that grows on both living and dead broad leaf

\footnotetext{
${ }^{\dagger}$ Corresponding author: Kwang-Won Yu, Department of Food and Nutrition, Korea National University of Transportation, Chungbuk 368-701, Korea. Tel: +82-43-820-5333, Fax: +82-43-820-5850, E-mail: kwyu@ut.ac.kr
} 
trees, and it is composed of numerous constituents such as polysaccharides, proteins, lectins, hericenone, erinacol, erinacine and terpenoids, in which some of their biological activities have been studied (Lee et al. 2000; Kenmoku et al. 2002). This mushroom has been used in several East Asian countries as an edible folk medicine to treat various human diseases, and thus it has attracted considerable attention to its various bioactive properties (Mizuno et al. 1992; Chang R 1996; Nakatsugawa et al. 2003). Erinacines and hericenones, compounds capable of promoting nerve growth factor (NGF) synthesis in cultured astrocytes, were isolated from the mycelium and fruiting body of $H$. erinaceum, respectively (Lee et al. 2000; Mori et al. 2008). It has been also reported to have cytotoxic effect on cancer cell lines, nematicidal and antimicrobial activities (Mizuno et al. 1992). Traditionally, this fungus has been produced by solid state culture process. Currently, industrial demand of most of metabolites is met by production in submerged culture. Agro-industrial residues are generally considered the best materials for the production of metabolites. There are a few reports on the production of carbohydrates with immunostimulating activities in culture broth of $H$. erinaceum mycelia (Lee et al. 2009). However, there is rarely reported about the active polysaccharide and the immunostimulating activity of mycelium cultured in mushroom complete medium (MCM), previously screened for the optimal basal medium (Park et al. 2010), supplemented with ginseng extract (GE) to enhance the activity.

Therefore, the aim of this study was to culture the enhanced immunomodulating $H$. erinaceum mycelium in MCM supplemented with $\mathrm{GE}(5,10$ and $15 \%$, v/v, a ratio of MCM volume to GE), and isolate the active polysaccharide fraction.

\section{MATERIALS AND METHODS}

\section{Materials}

Ginseng extract (GE) was prepared by decoction with water from Korean ginseng (Panax ginseng C. A. Meyer, 5-year cultivation) purchased from the Farming Association of Jeungpyeong-gun (Chungbuk, Korea), and evaporated to $65^{\circ} \mathrm{Bx}$ concentration. RPMI 1640 medium for the cultivation of animal cells were obtained from Gibco-BRL Co. (Grand Island, NY, USA). Fetal bovine serum (FBS) was purchased from Cell Culture Laboratories (Cleveland, $\mathrm{OH}, \mathrm{USA}$ ) and penicillin, streptomycin, and amphotericin B from Flow Laboratories (Irvine, Scotland). Cell counting kit (CCK)-8 was obtained from Dojindo Laboratories (Kumamoto, Japan).

\section{Microorganism and liquid culture}

Hericium erinaceum mushroom from the Agricultural Research and Extension Services of Chungbuk (Chungbuk, Korea) was used in this experiment. Mushroom complete medium (MCM) was selected as an optimal liquid medium of $H$. erinaceum in previous studies (Park et al. 2010), and contained the following: glucose (20 g), peptone (2 g), yeast extract (2 g), $\mathrm{K}_{2} \mathrm{HPO}_{4}(1$ g), $\mathrm{KH}_{2} \mathrm{PO}_{4}(0.4 \mathrm{~g})$, and $0.5 \mathrm{~g}$ of $\mathrm{MgSO}_{4} \cdot 7 \mathrm{H}_{2} \mathrm{O}$ per liter. The mycelium seed of $H$. erinaceum was cultivated in $250-\mathrm{m} \ell$ flask containing $100 \mathrm{ml}$ MCM supplemented with $5 \mathrm{ml}$ of $65^{\circ} \mathrm{Bx} \mathrm{GE}$ at $25^{\circ} \mathrm{C}$, pH 5.5 for 8 days. Finally, after $10 \%(2.5 \ell)$ of mycelia seed was inoculated, the liquid culture was carried out at $25^{\circ} \mathrm{C}$, $\mathrm{pH} 5.5,120 \mathrm{rpm}$ and an airflow rate of $0.4 \mathrm{vvm}$ for 5 days in a $50-\ell$ jar fermenter system (Fermenter Co. Ltd., Chungbuk, Korea) containing $25 \ell$ MCM supplemented with $1.25 \ell$ (GE-5\%, $\mathrm{v} / \mathrm{v}$, a ratio of MCM volume to GE), $2.5 \ell$ (GE-10\%) or $3.75 \ell$ (GE-15\%) of GE.

\section{Preparation of crude polysaccharide from mycelia}

After each mycelium recovered from liquid culture by centrifugation $\left(7,600 \times \mathrm{g}, 30 \mathrm{~min}, 4^{\circ} \mathrm{C}\right)$ was lyophilized and homogenized (Ultra-Turrax $^{\circledR}$ T-50, Janke \& Kunkel IKA-Labortechnik, Staufen, Germany), it was decocted with water to half volume and the residual materials were re-extracted by the same procedure (3 times). The combined extract was centrifuged to remove insoluble material, and then the supernatant was lyophilized to obtain hot-water extract. Hot-water extract was re-dissolved in water followed by addition of 5 volumes EtOH and stirring for $12 \mathrm{hr}$. The supernatant was separated, and then the resulting precipitate was dialyzed against deionized water (DIW). After dialysis, the non-dialyzable portion was lyophilized to obtain crude polysaccharide fraction (GE-5\%, HE-GE-5-CP; GE-10\%, HE-GE-10-CP; GE-15\%, HE-GE-15-CP). In order to confirm the enhanced immunomodulating activity of mycelium cultured in MCM supplemented with GE, hot-water extract and crude polysaccharide (HE-CP) from mycelium cultured in only MCM without GE (sample control) were also prepared.

\section{General method}

Total carbohydrate, uronic acid, and protein contents were determined by phenol- $\mathrm{H}_{2} \mathrm{SO}_{4}$ (Dubois et al. 1956), $m$-hydroxybiphenyl (Blumenkrantz \& Asboe-Hansen 1973), and Bradford method (Bradford MM 1976) with Bio-Rad dye (Bio-Rad, Hercules, CA, USA) by using galactose, galacturonic acid, and bovine serum 
albumin (BSA) as the respective standards. Component sugars of polysaccharides were analyzed as alditol acetates after hydrolysis of polysaccharides with $2 \mathrm{M}$ trifluoroacetic acid (TFA, SigmaAldrich, St. Louis, MO, USA) for $1.5 \mathrm{hr}$ at $121^{\circ} \mathrm{C}$ (Jones \& Albersheim 1972) and analyzed by gas-liquid chromatography (GLC). GLC was performed on an M600D gas chromatography (Young Lin Instrument Co., Gyeonggi-do, Korea) equipped with an SP-2380 capillary column $(0.2 \mu \mathrm{m}$ films, $0.25 \mathrm{~mm}$ i.d. $\times 30 \mathrm{~m}$, Supelco, Bellefonte, PA, USA) according to the procedure of Zhao et al. (1991). The molar ratios were calculated from the peak areas and response factors using the flame-ionization detector (FID).

\section{Fractionation of the active crude polysaccharide}

The immunomodulating crude polysaccharide (HE-GE-10-CP) from mycelia cultured in MCM supplemented with GE-10\% was applied to a column $(4.0 \times 30 \mathrm{~cm})$ of DEAE-Sepharose CL-6B ( $\mathrm{Cl}^{-}$form, Amersham Biosciences, Uppsala, Sweden) equilibrated with DIW. The column was eluted with DIW to obtain an unadsorbed fraction (HE-GE-10-CP-I). The adsorbed fractions were eluted by stepwise elution with $0.1 \sim 2.0 \mathrm{M} \mathrm{NaCl}$. Six adsorbed fractions (HE-GE-10-CP-II $\sim$ VII) were obtained as lyophilizates after dialysis $(0.1 \mathrm{M}$, HE-GE-10-CP-II; $0.2 \mathrm{M}$, HE-GE10-CP-III; 0.3 M, HE-GE-10-CP-IV; 0.4 M, HE-GE-10-CP-V; 0.5 M, HE-GE-10-CP-VI; 1.0 M, HE-GE-10-CP-VII). After HE-CP was also fractionated on the same column, unadsorbed fraction (HE-CP-I) and 6 adsorbed fractions (HE-CP-II $\sim$ VII) were obtained as sample control.

\section{Mice and cell culture}

The experimental protocol for measurement of immunomodulating activity was reviewed and approved by the Korea National University of Transportation Animal Care Committee. Specific pathogen-free $\mathrm{C} 3 \mathrm{H} / \mathrm{He}$ mice (female, 6-week old) were purchased from Orient Bio (Gyeonggi-do, Korea), BALB/c and ICR mice (female, 6-week old) for Nara Biotech Co., Ltd. (Gyeonggi-do, Korea). They were housed and maintained at a constant temperature, $24 \pm 1^{\circ} \mathrm{C}$ and humidity (55\%) with $12 \mathrm{hr}$ cycle of light and dark. They had access to commercial chew pellet diet, and water was freely available. A lung metastatic subline of a highly metastatic line of colon 26-M3.1 carcinoma cells were maintained as monolayer cultures in Eagle's minimum essential medium (EMEM) supplemented with 7.5\% FBS, sodium pyruvate, non-essential amino acids, and L-glutamate (Gibo-BRL Co.).

\section{Macrophage stimulating activity and cytokine pro-} duction

Six-week old ICR mice were injected interperitoneally with 1 $\mathrm{m} \ell$ of $3 \%$ thioglycollate medium. After $72 \mathrm{hr}$, macrophage cells were prepared from the peritoneal cavity of mice by washing twice with $5 \mathrm{~m} \ell$ of cold RPMI 1640 medium containing $5 \mathrm{mM}$ HEPES, penicillin (100 U/ml), and streptomycin $(100 \mu \mathrm{g} / \mathrm{m} \ell)$. An aliquot $(200 \mu)$ of the cell suspension $\left(1 \times 10^{6} \mathrm{cells} / \mathrm{m} \ell\right)$ was seeded in a flat-bottomed 96-well microplate. After incubation for $2 \mathrm{hr}$ at $37^{\circ} \mathrm{C}$ in a humidified atmosphere of $5 \% \mathrm{CO}_{2}-95 \%$ air, nonadherent cells were removed by washing twice with RPMI 1640 medium. The adherent macrophage monolayer was used for the following experiments (Conrad RE 1981). Macrophage stimulating activity was measured by the procedure of Suzuki et al. (1990) with slight modification. The adherent macrophage cells were cultured in the presence of test samples in a 96-well microplate for $24 \mathrm{hr}$. Macrophage monolayer in a 96-well microplate $\left(1 \times 10^{5}\right.$ cells $/ \mathrm{m} \ell$ ) was solubilized by the addition of $25 \mu \ell$ of $0.1 \%$ Triton $\mathrm{X}-100$. One-hundred-fifty $\mu l$ of $10 \mathrm{mM} p$-nitrophenyl phosphate was added to the reaction mixture, and absorbance at $405 \mathrm{~nm}$ was photometrically measured, using a microplate reader (Sunrise, Tecan, Grödinger, Austria). To confirm, meanwhile, macrophage stimulating effect of sample in cytokine level, interleukin (IL)-12 contents in the conditioned medium for macrophage culture was also measured by enzyme-linked immunosorbent (ELISA) assay kit (Pharmingen, San Jose, CA, USA) according to the manufacturer's recommendations.

\section{Intestinal immune system modulating activity through Peyer's patch}

The activity was measured according to $\mathrm{Yu}$ et al. (1998). Suspensions of Peyer's patch cells in RPMI 1640 medium supplemented with 5\% FBS (RPMI 1640-FBS) were prepared from a small intestine of $\mathrm{C} 3 \mathrm{H} / \mathrm{He}$ mice. One-hundred-eighty $\mu l$ of the cell suspension $\left(2 \times 10^{6}\right.$ cells $/ \mathrm{m} \ell$ in RPMI 1640-FBS) were cultured with $20 \mu l$ of test sample in a 96-well flat bottom microtiter plate for 5 days at $37^{\circ} \mathrm{C}$ in a humidified atmosphere of $5 \% \mathrm{CO}_{2}-95 \%$ air. Then, the resulting culture supernatant (50 $\mu \ell)$ was incubated with bone marrow cell suspension $\left(2.5 \times 10^{5}\right.$ cells $/ \mathrm{ml}$ ) from another $\mathrm{C} 3 \mathrm{H} / \mathrm{He}$ mice for 6 days in the same incubator. After $20 \mu l$ of CCK-8 solution was added to each well, the cells were continuously cultured for $4 \sim 12 \mathrm{hr}$. The intensity was measured to count to cell numbers with microplate reader at $450 \mathrm{~nm}$ during the cultivation according to Ishiyama et 
al. (1996).

\section{Anti-tumor metastasis using colon 26-m3.1 carcinoma cell}

Experimental lung metastasis was induced by intravenous (i.v.) inoculation of colon 26-MB.1 carcinoma cells $\left(3 \times 10^{4}\right)$ into BALB/c mice (Sung et al. 2006). To study the anti-tumor metastasis activity by fraction from mycelium cultured in MCM supplemented with GE, mice were given i.v. administration of sample (50 and $200 \mu \mathrm{g} /$ mouse, 4 mice/group, 30 31 g/mouse) 2 days before tumor cell inoculation. The mice were killed 14 days after tumor inoculation, and their lung were fixed in Bouin's solution followed by microscopically counting of lung tumor colonies.

\section{Statistical analysis}

Experimental results were presented as mean \pm S.D. The differences among all groups were analyzed by one-way ANOVA using the SPSS version 12.0 (SPSS Inc., Chicago, IL, USA). In addition, when significant difference was indicated, Duncan's multiple range test was performed to separate difference; the level of significance was $p<0.05$.

\section{RESULTS}

1. Enhancement of immunomodulating activity of crude Polysaccharide from mycelia cultured in mushroom complete medium supplemented with ginseng extract

After $H$. erinaceum mycelia were cultured in MCM supplemented with GE-5, 10 and 15\% or without GE using 50-1 jar fermenter system, each mycelium was recovered by centrifugation to find an effect of GE addition for fermentation as functional food materials. The lyophilized mycelia were extracted by hotwater and fractionated into crude polysaccharide fraction (GE-5\%, HE-GE-5-CP, yield against the dried mycelium 1.05\%; GE-10\%, HE-GE-10-CP, yield 2.23\%; GE-15\%, HE-GE-15-CP, yield 4.42\%; without GE, HE-CP, yield $1.33 \%$, Table 1) by EtOH precipitation to measure the immunostimulating activity. When the stimulating ability of macrophage recovered from abdominal cavity was investigated in vitro, HE-GE-10-CP showed significantly the higher activity ( 1.47 fold of saline control at $100 \mu \mathrm{g} / \mathrm{m} \ell)$ than HE-CP (1.25 fold) (Fig. 1A). On the other hand, HE-GE-5-CP (1.21 fold) was not significantly different with $\mathrm{HE}-\mathrm{CP}$, and HEGE-15-CP was 1.43 fold of saline control despite increase of GE concentration. HE-GE-10-CP also had the most intestinal immune

Table 1. Physicochemical properties of immunomodulating polysaccharides (HE-GE-10-CP-II and HE-CP-II)

\begin{tabular}{lcccc}
\hline \hline \multicolumn{1}{c}{ Fraction } & HE-CP & HE-CP-II & HE-GE-10-CP & HE-GE-10-CP-II \\
\hline Yield (\%) & 1.33 & 0.36 & 2.23 & 0.11 \\
\hline Chemical component content (\%) & & & \\
Neutral sugar & $86.73 \pm 4.18^{\mathrm{c} 2)}$ & $82.58 \pm 4.00^{\mathrm{bc}}$ & $62.33 \pm 4.27^{\mathrm{a}}$ & $77.43 \pm 4.76^{\mathrm{b}}$ \\
Uronic acid & $4.08 \pm 0.74^{\mathrm{a}}$ & $3.46 \pm 0.58^{\mathrm{a}}$ & $26.70 \pm 4.04^{\mathrm{c}}$ & $11.32 \pm 2.87^{\mathrm{b}}$ \\
Protein & $9.19 \pm 1.42^{\mathrm{a}}$ & $13.36 \pm 2.47^{\mathrm{b}}$ & $10.97 \pm 1.58^{\mathrm{ab}}$ & $11.25 \pm 0.63^{\mathrm{ab}}$ \\
\hline Component sugar (mole \%) & & & \\
Arabinose & & 0.36 & & 9.67 \\
Xylose & & 0.23 & & 0.38 \\
Rhamnose & & 0.37 & & 7.60 \\
Fucose & $\mathrm{ND}$ & 10.88 & $\mathrm{ND}$ & 5.44 \\
Mannose & & & 8.26 \\
Galactose & 18.55 & & 28.51 \\
Glucose & 33.83 & & 28.82 \\
Uronic acid & 32.32 & & 11.32
\end{tabular}

1) Yield (w/w \%) against the dried mycelia recovered by submerged culture.

${ }^{2)}$ Results expressed are mean \pm S.D. of quadruplicate samples, and means with different superscript letters were significantly different in each component $(p<0.05)$.

ND: These crude polysaccharides were not determined because crude polysaccharide contained various carbohydrates such as oligosaccharides, polysaccharides. 
A. Macrophage stimulating activity

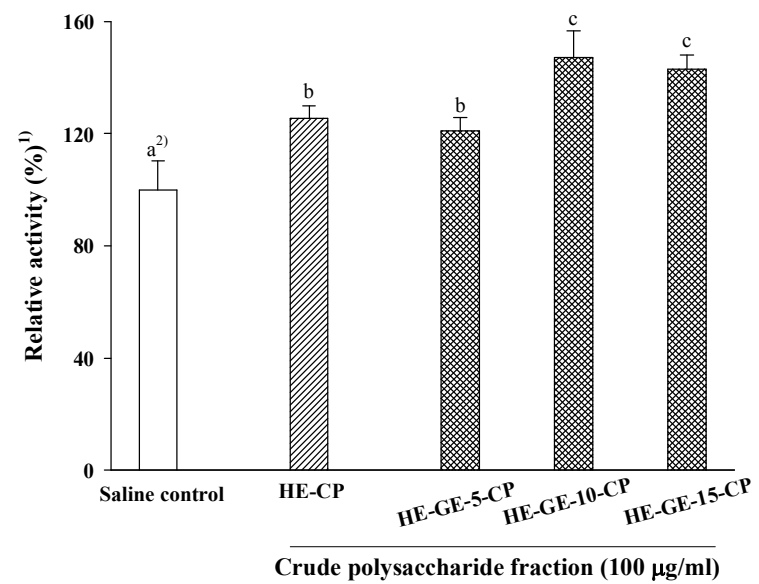

B. Intestinal immune system modualting activity through Peyer's patch

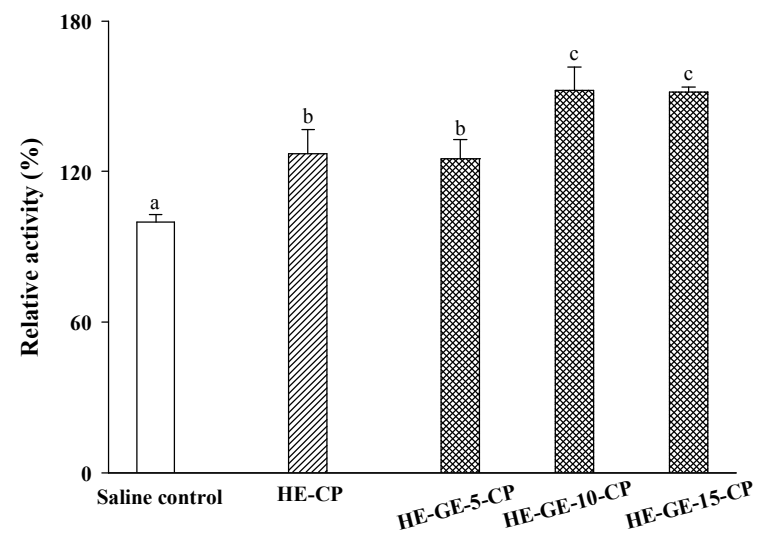

Crude polysaccharide fraction $(100 \mu \mathrm{g} / \mathrm{ml})$

Fig. 1. Immunomodulating activities of crude polysaccharides from Hericium erinaceum mycelia cultured in mushroom complete medium supplemented with ginseng extract. ${ }^{1)}$ Relative activity $(\%)=($ sample absorbance/saline control absorbance $) \times 100$.

${ }^{2)}$ Results expressed are mean \pm S.D. of quadruplicate samples, and means with different small letters are significantly different $(p<0.05)$.

system modulating activity through Peyer's patch (1.52 fold) among crude polysaccharides from mycelia cultured in MCM added with GE, and the potently enhanced activity as compared with HE-CP (1.27 fold) (Fig. 1B). These results suggested a possibility that immunomodulating activity of mycelium was enhanced with supplementation of ginseng extract, especially GE- $10 \%$, in the submerged culture.

2. Immunomodulating activities of subfractions from crude polysaccharide on DEAE-Sepharose CL-6B column chromatography
In our previous research, we found that the active crude polysaccharides fractionated from hot-water extracts by $\mathrm{EtOH}$ precipitation consisted of macromolecule, such as polysaccharide (Yu et al. 1998; Kim et al. 2010). Thus, crude polysaccharide fractionated from $H$. erinaceum cultured in the medium with GE or without GE was also assayed in order to elucidate whether macromolecule contributes to the immunostimulating activity. Although all crude polysaccharides contained neutral sugar, uronic acid and protein, contents of neutral sugar and uronic acid in HE-GE-10-CP (62.33 and 26.70\%, respectively) was significantly

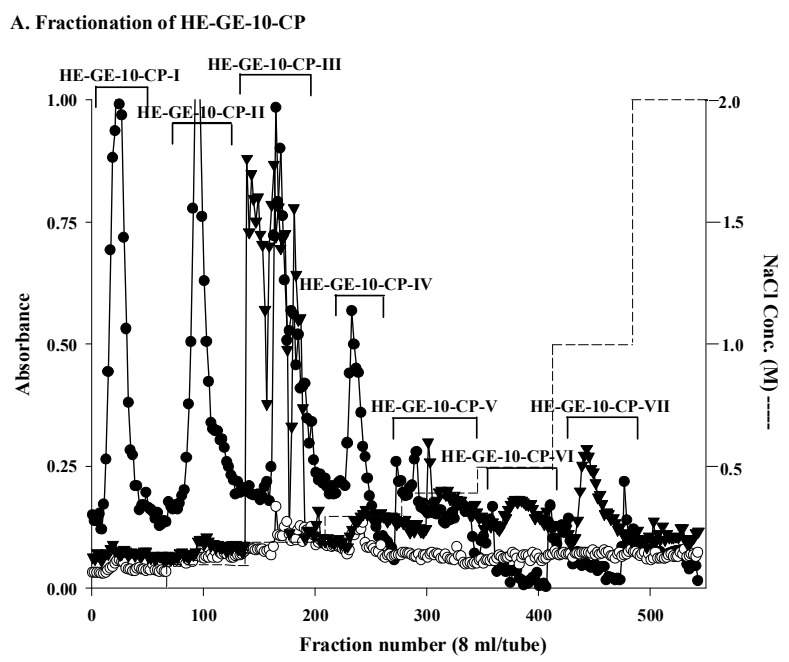

B. Fractionation of HE-CP

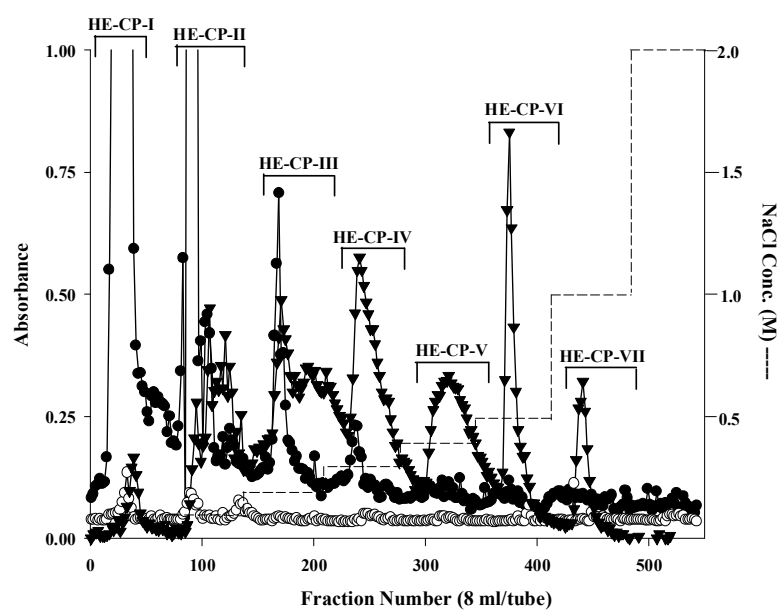

Fig. 2. Comparison of elution profiles of crude polysaccharides from Hericium erinaceum cultured in mushroom complete medium supplemented with ginseng extract (HE-GE10-CP) and without (HE-CP) on DEAE-Sepharose CL-6B column chromatography ( $\mathrm{Cl}^{-}$form). Column size; $4.0 \times 30 \mathrm{~cm}$. -) neutral sugar $(490 \mathrm{~nm}), \bigcirc$; uronic acid $(520 \mathrm{~nm}), \boldsymbol{\nabla}$; protein $(280 \mathrm{~nm})$. 
different from HE-CP (86.73 and 4.08\%) (Table 1). When HE-GE10-CP was further fractionated by anion-exchange column chromatography on DEAE-Sepharose CL-6B ( $\mathrm{Cl}^{-}$form) to identify polysaccharide with the enhanced activity from HE-GE-10-CP, an unadsorbed (HE-GE-10-CP-I; yield of the dried mycelia, 0.17\%) and 6 adsorbed fractions (HE-GE-10-CP-II VII; yield 0.11, 0.35, 0.12, 0.06, 0.01 and $0.01 \%$, Table 1) were obtained (Fig. 2A). Meanwhile, HE-CP was fractionated into an unadsorbed (HE-CP-I, yield $0.18 \%$ ) and 6 adsorbed fractions (HE-CP-II VII; yield 0.14,

\section{A. Lysosomal enzyme activity in macrophage}

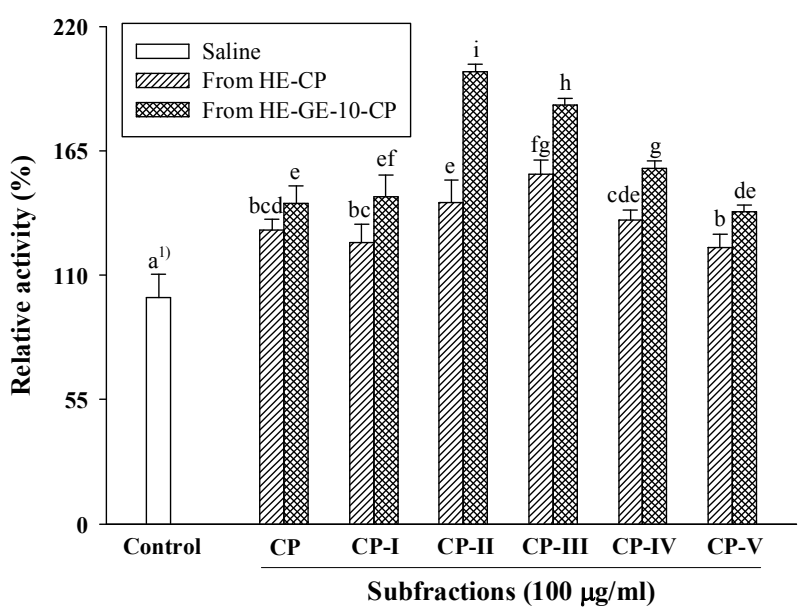

B. IL-12 production from macrophage

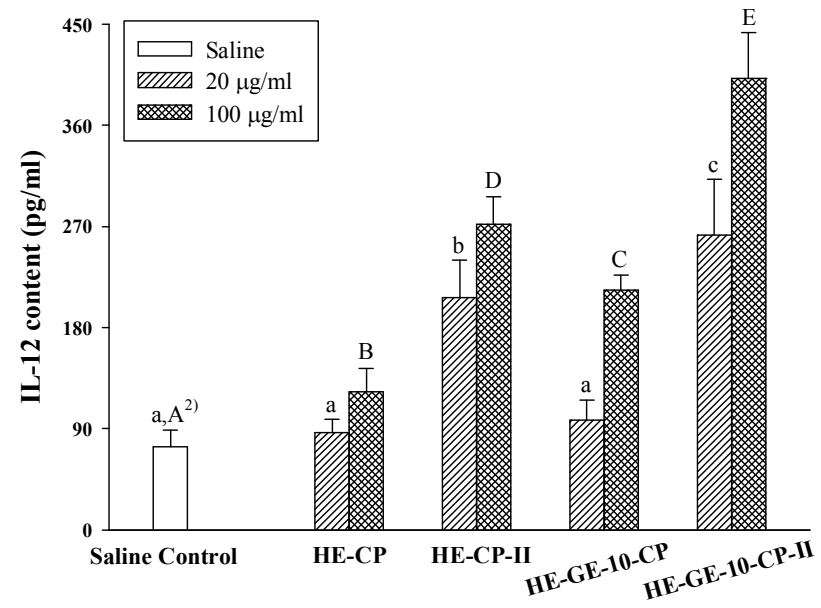

Fig. 3. Macrophage stimulating activity of subfractions from crude polysaccharide (HE-GE-10-CP or HE-CP) on DEAESepharose CL-6B column chromatography ( $\mathrm{Cl}^{-}$form). Results expressed are mean \pm S.D. of a quadruplicate samples. ${ }^{1)}$ Means with different small letters were significantly different, and ${ }^{2)}$ means with different small $(20 \mu \mathrm{g} / \mathrm{m} \ell)$ or large letters $(100$ $\mu \mathrm{g} / \mathrm{m} \ell)$ were significantly different $(p<0.05)$.
0.11, 0.08, 0.04, 0.02 and 0.01\%) (Fig. 2B), and chromatography profile and each subfraction yield of HE-GE-10-CP and HE-CP were seemed to be a different polysaccharide. When the macrophage stimulating activities of the subfractions were compared, HE-GE-10-CP-II showed the most potent activity in subfractions of HE-GE-10-CP and higher activity than HE-CP-II or III, which had the highest activity in HE-CP subfractions (Fig. 3A). The activated macrophages are known to secrete such as IL-12, which stimulate the activation of natural killer (NK) cell or T cell. To understand whether HE-GE-10-CP-II enhanced IL-12 secretion by the macrophage activation, IL-12 level of the supernatant from cultivation with sample and macrophage was examined. The amount of IL-12 in the conditioned medium of HE-GE-10-CP-II increased significantly in comparison with HE-CP-II at $100 \mu \mathrm{g} / \mathrm{m} \ell$ (1.47 fold) (Fig. 3B). In addition, the effect of HE-GE-10-CP-II on how Peyer's patch cells-mediated the hematopoietic responses of bone marrow cells was investigated. As shown in Fig. 4, bone marrow cells proliferation almost reached a plateau in HE-GE10-CP-II and increased by up to 1.23 fold of HE-CP-II. The tumor metastasis inhibition of lung cancer from subfraction obtained by DEAE- Sepharose CL-6B was also tested. HE-GE-10-CP-II showed more potent activity (61.5\%) than HE-CP-II (44.6\%) in dose of $200 \mu \mathrm{g} /$ mouse (Table 2).

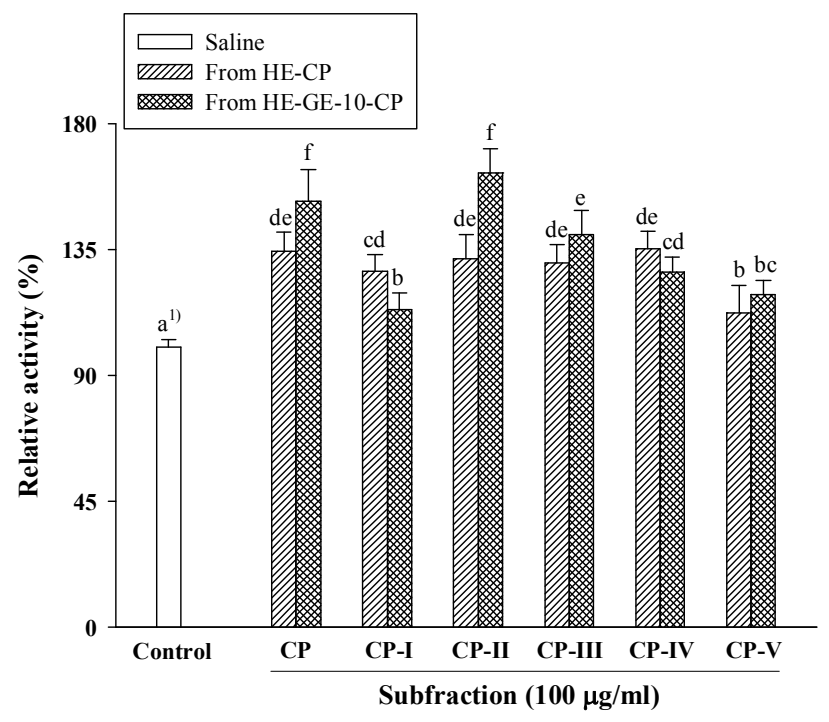

Fig. 4. Intestinal immune system modulating activities through Peyer's patches of subfractions from crude polysaccharide (HE-GE-10-CP or HE-CP) on DEAE-Sepharose CL-6B column chromatography (Cr form). ${ }^{1)}$ Results expressed are mean \pm S.D. of a quadruplicate samples, are means with different small letters were significantly different $(p<0.05)$. 
Table 2. Anti-metastatic activities of immunostimulating polysaccharides (HE-GE-10-CP-II and HE-CP-II) in colon 26-M3.1 carcinoma model

\begin{tabular}{|c|c|c|c|}
\hline \multirow{2}{*}{ Fraction } & \multicolumn{3}{|c|}{ Number of metastatic colony (inhibition of tumor metastasis, $\%)^{1)}$} \\
\hline & $0 \mu \mathrm{g} / \mathrm{mouse}$ & $50 \mu \mathrm{g} / \mathrm{mouse}$ & $200 \mu \mathrm{g} / \mathrm{mouse}$ \\
\hline Saline $_{\text {control }}^{2)}$ & $124.0 \pm 7.9^{\mathrm{d} 3)}(0.0)$ & - & - \\
\hline HE-CP & - & $90.2 \pm 5.2^{\mathrm{c}}$ & $77.7 \pm 7.4^{\mathrm{c}}$ \\
\hline HE-CP-II & - & $83.3 \pm 6.3^{\mathrm{bc}}$ & $68.8 \pm 4.8^{\mathrm{bc}}(44.6)$ \\
\hline HE-GE-10-CP & - & $74.5 \pm 7.0^{\mathrm{ab}}(39.9)$ & $63.5 \pm 6.9^{\mathrm{b}}(48.8)$ \\
\hline HE-GE-10-CP-II & - & $69.8 \pm 5.9^{\mathrm{a}}$ & $47.8 \pm 6.1^{\mathrm{a}} \quad(61.5)$ \\
\hline \multicolumn{4}{|c|}{$\begin{array}{l}\text { Inhibition of tumor metastasis }=[\text { No. of colony in the control-No. of colony in each fraction }] / \text { No. of colony in the control }] \times 100 \text {. } \\
\text { Control: tumor control group treated saline without fraction. }\end{array}$} \\
\hline
\end{tabular}

\section{Properties of the active polysaccharide fractionated} from mycelia cultured in MCM supplemented with GE-10\%

HE-GE-10-CP-II with the enhanced immunostimulating and anti-metastatic activity fractionated from $H$. erinaceum cultured in MCM supplemented with GE-10\% mainly contained neutral sugar (77.43\%) and uronic acid (11.32\%) in addition to small amount of protein (3.25\%). Although less active polysaccharide fraction (HE-CP-II) from mycelium in MCM without GE also comprised about $82.58 \%$ of neutral sugar, HE-CP-II consisted of only a little protein and uronic acid (5.36 and 3.46\%, respectively). Although two polysaccharide fractions were different in chemical component (Table 1), alditol acetate preparation and GC analysis were applied to clarify the compositional difference between HE-GE-10-CP-II and HE-CP-II. Component sugar analysis showed that HE-GE-10-CP-II consisted mainly of arabinose, rhamnose, galactose, glucose and uronic acid (molar ratio of 0.34:0.26:0.99:1.00:0.39). However, HE-CP-II was contained a small amount of uronic acid and mainly composed of neutral sugars such as fucose, mannose, galactose and glucose (molar ratio of 0.32:0.55:1:00:0.96) (Table 1). It is suggested that the enhanced activity of HE-GE-10-CP-II resulted from the changed composition of mycelium polysaccharide.

\section{DISCUSSION}

Mushroom-derived polysaccharides have been shown to exhibit anti-tumor effect by stimulating natural killer cells, T-cells, B-cells, and elicit macrophage-dependent immune system responses (Mizuno et al. 1992; Wasser SP 2002). In addition, mushroom-derived polysaccharides are known to have no toxic side effects, unlike the existing anti-cancer chemical medications. Therefore, when used as a cancer therapeutic, these polysaccharides were able to prolong the life span of cancer patient (Deng et al. 2009; Benjamini \& Leskowitz 1991). As such, polysaccharides derived from mushrooms appear to have potentially beneficial immunepharmacological properties (Wasser SP 2002).

Recently, mass production of mushroom or fungi has been successfully established through artificial cultivation and they are currently produced on a large scale. Although most investigators have sought to cultivate these mushroom or fungi on a solid media, it may be more advantageous to do so in submerged media (Choi et al. 1999). Submerged cultures of entomopathogenic fungi give rise to higher productivity of mycelia biomass and exo-polysaccharide in a more compact space, within a shorter period of time, and with less chance of contamination when compared with those cultivated on solid media (Kim et al. 2003).

Hericium erinaceum a well known traditional edible and medicinal mushroom belongs to the Aphyllophorales, Hydnaecae, and Hericium families. H. erinaceum is widely distributed in East-Asian counties including Korea, Japan, and China. Many studies have demonstrated that $H$. erinaceum possess anti-microbial (Okamoto et al. 1993), anti-tumor (Mizuno et al. 1992; Kwon et al. 2003), anti-oxidant (Mau et al. 2002), cytotoxic (Kawagishi et al. 1990), and immunomodulatory (Liu et al. 2002) properties. To our knowledge, however, there is no report on the enhanced immunomodulatory effect of $H$. erinaceum mycelium cultured in medium added ginseng extract. The present study reports the enhanced effect of $H$. erinaceum cultured in normal medium supplemented with ginseng extract on the immune response.

In this study, crude polysaccharide (HE-GE-10-CP) from 
Hericium erinaceum cultured in mushroom complete medium (MCM) supplemented with ginseng extract (GE) has been found to enhance the immunomodulating activity. Supplementation with GE-10\% in MCM had significantly increased macrophage stimulating and intestinal immune system modulating activity compared with crude polysaccharide (HE-CP) from mycelium in MCM culture without GE (Fig. 1). These results suggested a possibility that immunostimulating activity of mycelium was enhanced with supplementation of ginseng extract, especially GE- $10 \%$, in the submerged culture. In addition, the chemical component content of HE-GE-10-CP was significantly different from HE-CP, suggesting that polysaccharide was related with the enhanced immunological activity. When HE-GE-10-CP was fractionated by anion-exchange column chromatography to identify the compositional difference from HE-CP, the most active polysaccharide fraction (HE-GE-10-CP-II) had higher immunostimulating and anti-metastatic activity than any subfraction from HE-CP (Fig. 3 and 4). Component sugar analysis also showed that HE- GE-10-CP-II contained uronic acid as well as arabinose, rhamnose, galactose and glucose as major neutral sugars. However, HE-CP-II, which was the active subfraction of HE-CP eluted at the same $\mathrm{NaCl}$ concentration $(0.1 \mathrm{M})$, consisted mainly of fucose, mannose, galactose and glucose and a few amount of uronic acid (Table 1).

In previous researches about component sugar of $H$. erinaceum, the antioxidant polysaccharide from mycelium mainly comprised major sugar such as galactose, glucose and mannose (Malinowska et al. 2009), and fruiting body consisted mainly of glucose, galactose and small amount of fucose (Wang et al. 2004). These reports were consistent with our results in terms of major component sugar was glucose and galactose, and uronic acid is less, suggesting that component sugar of mycelium was affected by GE-addition for fermentation. Since ginseng extract contained generally pectic polysaccharide including uronic acid, galactose, rhamnose and arabinose (Zhang et al. 2009; Fan et al. 2010), increase of arabinose, rhamnose and uronic acid in HE-GE-10-CP-II was also related with effect of GE-addition on component sugar of mycelium polysaccharide. Therefore, it is assumed that the polysaccharide change of mycelium culture by GE-addition plays an important role for expression of its enhanced activity. Studies for structure and structure-activity relationships of the active polysaccharides are in progress now.

Numerous studies in animal models demonstrated that tumor metastasis inhibition by biological response modifiers (BRMs) was associated with the activation of innate immunity (Mukai et al. 1995). Although the Korean ginseng have been used in treating various diseases in East Asian countries including Korea, only little evidence has been established on the anti-tumor activity of $H$. erinaceum mycelium cultivated in MCM supplemented with GE either in vitro or in vivo. To investigate whether the immunostimulating polysaccharide (HE-GE-10-CP-II) inhibited tumor metastasis or not, we examined the prophylactic effect of sample on the experimental lung metastasis, which was induced by colon 26-M3.1 carcinoma cells. Intravenous administration (200 $\mu \mathrm{g} /$ mouse) of HE-GE-10-CP-II 2 days before tumor inoculation showed more significantly anti-metastasis of colon 26-M3.1 cells than HE-CP-II from mycelium cultured in MCM without GE (Table 2). Immunological approaches to protect against cancer are broadly classified into the therapies (innate or adaptive) in which cancer cell-specific and non-specific immunological mechanisms are involved (Mukai et al. 1995). In this study, we have investigated whether HE-GE-10-CP-II would have an immune stimulant role in enhancing host defense system against metastatic tumors and their effect on innate immune effector cell activation after treatment of sample in mice. In experimental tumor metastasis model, BRMs from mycelium have been deemed useful for suppressing tumor growth, and inhibiting tumor metastasis. This suggests that the anti-tumor effect of HE-GE- 10-CP-II was based on the activation of natural immunity. Unlike conventional chemotherapeutic agents, these compounds are safe in vivo because they are shown to be relatively nontoxic to normal cells and enhance host defense systems by stimulating immune-related cells. Really, HE-GE-10-CP-II did not show direct cytotoxicity against tumor cells but proliferated immune cells and normal splenocytes in vitro. Although the exact mechanism of their anti-tumor activity has not been clearly elucidated, innate immune system activation, including macrophage, Peyer's patch cells, may play a role in their activity.

\section{CONCLUSION}

The objectives of this study were to investigate the enhancement of immunomodulating activity of Hericium erinaceum mycelia cultured in mushroom complete medium (MCM) supplemented with ginseng extract $\left(\mathrm{GE}, 65^{\circ} \mathrm{Bx}\right)$, and to fractionate the active polysaccharide from mycelia. When the activities of crude polysaccharides (HE-GE-5-CP, HE-GE-10-CP and HE-GE-15-CP) fractionated from mycelia cultured in MCM supplemented with GE of 5,10 and $15 \%(\mathrm{v} / \mathrm{v}$, a ratio of MCM volume to GE) were 
evaluated, HE-GE-10-CP showed the significantly enhanced immunomodulating activity compared with crude polysaccharide (HE-CP) from mycelia cultured in only MCM without GE. After HE-GE10-CP was further fractionated on DEAE-Sepharose CL-6B, the most active fraction (HE-GE-10-CP-II) showed significantly higher immunomodulating activities and anti-metastasis than any subfraction from HE-CP. Component sugar analysis also indicated that HE-GE-10-CP-II consisted mainly of arabinose, rhamnose, galactose, glucose and uronic acid (molar ratio; 0.34:0.26:0.99: 1.00:0.39) whereas less active fraction (HE-CP-II) from HE-CP mainly comprised fucose, mannose, galactose and glucose (molar ratio; 0.32:0.55:1.00:0.96). Therefore, these results suggested that the ginseng extract supplementation to medium for culture of $H$. erinaceum mycelium affected component sugar of mycelium and resulted in enhancement of immunomodulating activity, and it is assumed to be a useful tool to develop functional materials through submerged culture.

\section{ACKNOWLEDGEMENTS}

The research was supported by a grant from the Academic Research Program of Korea National University of Transportation in 2012. The authors thank its financial support.

\section{REFERENCES}

Benjamini E, Leskowitz S. 1991. Immunology: A Short Course. 2nd ed. Wiley-Liss, New York, USA

Blumenkrantz N, Asboe-Hansen G. 1973. New method for quantitative determination of uronic acids. Anal Biochem $54: 484-489$

Bradford MM. 1976. A rapid and sensitive method for the quantitation of microgram quantities of protein utilizing the principle of protein-dye binding. Anal Biochem 72:248-254

Chang, R. 1996. Functional properties of edible mushrooms. Nutr Rev 54:S91-S93

Choi IY, Choi JS, Lee WH, Yu YJ, Joung GT, Ju IO, Choi YK 1999. The condition of production of artificial fruiting body of Cordyceps militaris. Korean J Mycol 27:243-248

Conrad RE. 1981. Induction and collection of peritoneal exudates macrophages. In: Manual of Macrophage Methodology, Herscowitz BH, Holden HT, Bellanti JA, Ghaffar A, eds. p. 5-11. Marcel Dekker, New York, USA

Deng G, Lin H, Seidman A, Fornier M, D’Andrea G, Wesa K,
Yeung S, Cunningham-Rundles S, Vickers AJ, Cassileth B. 2009. A phase I/II trial of a polysaccharide extract from Grifola frondosa (maitake mushroom) in breast cancer patients: Immunological effects. J Cancer Res Clin Oncol 135:12151221

Dubois M, Gilles KA, Hamilton JK, Rebers PA, Smith F. 1956. Colorimetric method for determination of sugars and related substances. Anal Chem 28:350-356

Fan Y, Cheng H, Li S, Wang J, Liu D, Hao M, Gao X, Fan E, Tai G, Zhou Y. 2010. Relationship of the inhibition of cell migration with the structure of ginseng pectic polysaccharides. Carbohydr Polym 81:340-347

Fisher M, Yang LX. 2002. Anticancer effects and mechanisms of polysaccharide-K (PSK): Implications of cancer immunotherapy. Anticancer Res 22:1737-1754

Ishiyama M, Tominaga H, Shiga M, Sasamoto K, Ohkura Y, Ueno K. 1996. A combined assay of cell viability and in vitro cytotoxicity with a highly water-soluble tetrazolium salt, neutral red and crystal violet. Biol Pharm Bull 19: $1518-1520$

Isoda N, Equchi Y, Nukava H, Hosho K, Suga Y, Suga T, Nakazawa S, Sugano, K. 2009. Clinical efficacy of superfine dispersed lentinan ( $\beta$-1,3-glucan) in patients with hepatocellular carcinoma. Hepatogastroenterology 56:437-441

Jones TM, Albersheim PA. 1972. A gas chromatographic method for the determination of aldose and uronic acid constituents of plant cell wall polysaccharide. Plant Physiol 49:926-936

Kawagishi H, Ando M, Mizuno T. 1990. Hericenone A and B as cytotoxic principles from the mushroom Hericium erinaceum. Tetrahedron Lett 31:373-376

Kenmoku H, Shimai T, Toyomasu T, Kato N, Sassa T. 2002. Erinacine Q, a new erinacine from Hericium erinaceum, and its biosynthetic route to erinacine $\mathrm{C}$ in the basidiomycete. Biosci Biotechnol Biochem 66:571-575

Kim D, Lee J, Kim KJ, Hong HC, Shin KS, Yu KW. 2010. Macrophage stimulating polysaccharide purified from peels of grape (Vitis labrusca). Food Sci Biotechnol 19:479-486

Kim SW, Xu CP, Hwang HJ, Choi JW, Kim CW, Yun JW. 2003. Production and characterization of exopolysaccharides from an entomopathogenic fungus Cordyceps militaris NG3. Biotechnol Prog 19:428-435

Kwon SH, Kim CN, Kim CY, Kwon ST, Park KM, Hwangbo S. 2003. Antitumor activities of protein-bound polysaccharide extracted from mycelia of mushroom. Korean J Food Nutr 
$16: 15-21$

Lee EW, Shizuki K, Hosokawa S, Suzuki M, Suganuma H, Inakuma T, Li J, Ohnishi-Kameyama M, Nagata T, Furukawa S, Kawagish H. 2000. Two novel diterpenoids, erinacines $\mathrm{H}$ and I from the mycelia of Hericium erinaceum. Biosci Biotechnol Biochem 64:2402-2405

Lee JS, Cho JY, Hong EK. 2009. Study on macrophage activation and structural characteristics of purified polysaccharides from the liquid culture broth of Hericium erinaceus. Carbohydr Polym 78:162-168

Liu CP, Fang JN, Li XY, Xiao XQ. 2002. Structural characterization and biological activities of SC4, an acidic polysaccharide from Salvia chinensis. Acta Pharmacol Sin 23: 162-166

Malinowska E, Krzyczkowski W, Herold F, Łapienis G, Ślusarczyk J, Suchocki P, Kuraś M, Turło J. 2009. Biosynthesis of selenium-containing polysaccharides with antioxidant activity in liquid culture of Hericium erinaceum. Enzyme Microb Technol 44:334-343

Mau JL, Lin HC, Song SF. 2002. Antioxidant properties of several specialty mushrooms. Food Res Int 35:519-526

Mizuno T, Wasa T, Ito H, Suzuki C, Ukai N. 1992. Antitumoractive polysaccharides isolated from the fruiting body of Hericium erinaceum, an edible and medicinal mushroom called yamabushitake or houtou. Biosci Biotechnol Biochem 56:347-348

Mori K, Obara Y, Hirota M, Azumi Y, Kinugasa S, Inatomi S, Nakahata N. 2008. Nerve growth factor-inducing activity of Hericium erinaceus in 1321N1 human astrocytoma cells. Biol Pharm Bull 31:1727-1732

Mukai S, Kato H, Kimura S, Asai K, Kawahito Y, Inoue M, Yamamura Y, Sano H, Sugino S, Shu S, Kondo M. 1995. Adoptive immunotherapy of poorly immunogenic tumors with in vitro sensitized cells generated by intratumoral administration of biological response modifiers. Int J Immunopharmacol 17:963-971

Nakatsugawa M, Takahashi H, Takezawa C, Nakajima K, Harada K, Sugawara Y, Kobayashi S, Kondo T, Abe S. 2003. Hericium erinaceum (yamabushitake) extract-induced acute respiratory distress syndrome monitored by serum surfactant proteins. Intern Med 42:1219-1222

Okamoto K, Sakai T, Shimada A, Shirai R, Sakamoto H, Yoshida S, Ojima F, Ishiguro Y, Kawagishi H. 1993. Antimicrobial chlorinated orcinol derivatives from mycelia of Hericium erinaceum. Phytochemistry 34:1445-1446

Park CK, Tu Q, Cho JH, Yu KW, Jeong HS, Lee HY, Jeong JH. 2010. Optimum conditions for the culture of Hericium erinaceum in a jar fermenter with the addition of ginseng extract in the liquid medium. Korean J Food Sci Technol 42:82-89

Sung JY, Yoon TJ, Yu KW, Lee KH, Lee H. 2006. Enhancement of immunological activities in mice by oral administration of pectic polysaccharides from Eleutherococcus senticosus. Food Sci Biotechnol 15:117-121

Suzuki I, Tanaka H, Kinoshita A, Oikawa S, Osawa M, Yadomae T. 1990. Effect of orally administered beta-glucan on macrophage function in mice. Int $J$ Immunopharmacol 12:675-684

Wang Z, Luo D, Liang Z. 2004. Structure of polysaccharides from the fruiting body of Hericium erinaceus Pers. Carbohydr Polym 57:241-247

Wasser SP. 2002. Medicinal mushrooms as a source of antitumor and immunomodulating polysaccharides. Appl Microbiol Biotechnol 60:258-274

Yoon TJ, Yu KW, Shin KS, Suh HJ. 2008. Innate immune stimulation of exo-biopolymers prepared from Cordyceps sinensis by submerged culture. Appl Microbiol Biotechnol 80:1087-1093

Yu KW, Kiyohara H, Matsumoto T, Yang HC, Yamada H. 1998. Intestinal immune system modulating polysaccharides from rhizomes of Atractylodes lancea. Planta Med 64:714-719

Yu KW, Kim YS, Shin KS, Kim JM, Suh HJ. 2005. Macrophagestimulating activity of exo-biopolymer from cultured rice bran with Monascus pilosus. Appl Biochem Biotechnol 126 $35-48$

Zhang X, Yu L, Bi H, Li X, Ni W, Han H, Li N, Wang B, Zhou Y, Tai G. 2009. Total fractionation and characterization of the water-soluble polysaccharides isolated from Panax ginseng C. A. Meyer. Carbohydr Polym 77:544-552

Zhao JF, Kiyohara H, Yamada H, Takemoto N, Kawamura H. 1991. Heterogeneity and characterization of mitogenic and anti-complementary pectic polysaccharides from the roots of Glycyrrhiza uralensis Fisch et D.C. Carbohydr Res 219: 149-172

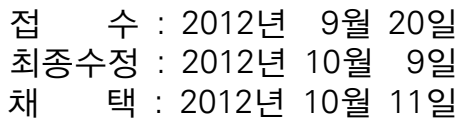

